\title{
Polysèmes
}

Revue d'études intertextuelles et intermédiales

\section{Baroque Parody in Brigid Brophy's In Transit}

La parodie baroque dans In Transit de Brigid Brophy

Justine Gonneaud

\section{OpenEdition}

\section{Journals}

Electronic version

URL: http://journals.openedition.org/polysemes/7701

DOI: 10.4000/polysemes.7701

ISSN: 2496-4212

\section{Publisher}

SAIT

\section{Electronic reference}

Justine Gonneaud, « Baroque Parody in Brigid Brophy's In Transit », Polysèmes [Online], 23 | 2020,

Online since 30 June 2020, connection on 02 July 2020. URL : http://journals.openedition.org/ polysemes/7701; DOI : https://doi.org/10.4000/polysemes.7701

This text was automatically generated on 2 July 2020.

Polysèmes 


\title{
Baroque Parody in Brigid Brophy's In Transit
}

\author{
La parodie baroque dans In Transit de Brigid Brophy
}

Justine Gonneaud

1 Brigid Brophy's In Transit, published in 1969, is a complex experimental novel that depicts the adventures of Pat(ricia) O'Rooley, who is stuck in the transit lounge of an airport. Initially written as a first-person narrative, the main plot takes a surreal turn, when the main character and focalizer realizes $\mathrm{s} /$ he has forgotten his/her biological sex, effectively barring him/her from crossing the airport's boarding gates. A picaresque quest for this missing piece of information through the airport's transit lounge, lavatories and staff locker room ensues, following the character's multiple attempts to deduce his/her sex from clues, attitudes, and dialogues with other characters. Throughout the novel, each new effort to decipher signs and behaviors takes the form of a different literary genre, artistic form or media, be it the opera, the detective story, the pornographic novel, or the televised game show, while the narrative shifts to a third-person voice which alternatively describes Pat as Patrick or Patricia. The quest for the "missing (re)member" (62) is a pretext to experiment with the limits of various discourses and conventions-whether social, literary or linguistic -in order to explore their impact on our notions of identity, effectively demonstrating that gender is but performative and fluid, before this notion was brought to fame by queer theorist Judith Butler in the 1990s. In this instance, I would like to examine the prominent role of metafictional parody in both establishing and subverting the link between discourses and ultimately language itself with gender identities.

2 The ambivalent dynamics consisting in simultaneously stating and undermining a referential frame is at the core of many contemporary theories of parody. For Linda Hutcheon, "parody always implicitly reinforces even as it ironically debunks" (1985, xii). While parody may be, as noted by Jameson, "an inscription of the past in the present", it is also a powerful form of art that can be used "with a variety of interventionist social agendas focused on issues such as gender, class, sexual choice, race, ethnicity and so on" and a "wide variety of tones and moods-from respectful to 
playful to scathingly critical" (Hutcheon xii). Although parody may be deemed conservative or imitative rather than creative and productive, due to the reproduction of past forms of writing that it implies, Hutcheon chose "to define parody as a form of repetition with ironic critical distance, marking difference rather than similarity", for "[t]he tension between the potentially conservative effect of repetition and the potentially revolutionary impact of difference is one common denominator shared by all the many and varied art forms [she] examined" (xii). Similarly, Margaret Rose defines parody as essentially ambivalent regarding its hypotext, an uncertainty that can be detected in the very etymology of the term: "an ambiguity exists in the word 'parodia' in that the prefix 'para' can be translated to mean both nearness and opposition. [It] may be said to develop two trends of meaning, being used to express such ideas as nearness, consonance and derivation as well as transgression, opposition, or difference" (Rose 48).

Bearing in mind the fundamentally ambivalent dimension that both critics defined as a prominent feature of parody, I would like to focus on the various attitudes of the author towards the parodied texts, subtly ranging from sympathy to criticism. I will consider first the novel conceived as a laboratory dedicated to test and experiment on the literary conventions of various genres. This will lead me to explore the relationship between the notions of genre and gender, and to demonstrate the simultaneous subversion of both literary and gendered norms. Finally, I will highlight the entropic motifs of disintegration and explosion that delineate a self-proclaimed baroque aesthetics of parody based on the destruction of gendered, literary but also linguistic norms.

\section{Un/sympathetic parody}

4 According to Rose, "most parody worthy of the name is ambivalent towards its target. This ambivalence may entail not only a mixture of criticism and sympathy for the parodied text, but also creative expansion of it into something new" (Rose 51). In keeping with Rose's description of parody as being both sympathetic and critical toward the hypotext it imitates, Brigid Brophy takes a dual approach to intertextuality, mixing reverence and admiration to criticism and distanciation.

5 Many of Brophy's academic critics noted the macrostructural parody of landmark novels by male counterparts such as Laurence Sterne's Tristram Shandy and James Joyce's Finnegans Wake and Ulysses. For Carole Sweeney, In Transit is a "baroque marriage of Joycean badinage, typographic experiments, Steinian punnery and Sternean metanarrative digressiveness" (Sweeney 310), while its plot certainly owes to Virginia Woolf's Orlando (313). Indeed, the narrator's multiple digressions and his/her repeated direct addresses to the reader, which constantly delay the action and thwart expectations during an always eschewed search for the true sex of the character, may evoke Sterne's style. Moreover, some of Brophy's formal techniques gesture towards those of Laurence Sterne in Tristram Shandy: the textual inclusion of visual representations of elements of the plot, such as the voucher given to Pat as a reward (Brophy 139), her schematic representations of the movements of the characters (171; 172), the splitting of the text into two columns for simultaneous actions (165-177), the varying length of the chapters, sometimes reduced to one single sentence (227), and the use of curly brackets to provide two reading options within the same line (115) all bring 
to mind the blank, black and marbled pages (Sterne $331 ; 22 ; 165-166$ ), the reproduction of Yorick's epitaph (23) and the lines visually representing the progression (or lack thereof) of the narrative (333).

6 As mentioned above by Sweeney, the second main hypotext for In Transit can be found in Joyce. For David Vichnar, "Brophy clearly aligns her experimentation, however mock-seriously, with what she recognises as Joyce's anti-imperialist, de-colonising linguistic project" (Vichnar 2014). For instance, the use of portmanteau words, and compulsive punning in the novel-or "the grips of compunsion" (35), as Pat terms italong with the Babelian mix of languages that mirror the international dimension of the airport might be traced back to Joyce's Finnegans Wake. More specifically, "Brophy's novel acknowledges what is often repressed in discussions of postmodernism-its profound debt to, and anxiety of influence toward, modernism. Brophy's anarchic text exposes its own underpinning, one might call it, in Joyce's work" (Lawrence 172). Indeed, Brophy explicitly and repeatedly pays tribute to her Irish compatriot. As Pat acknowledges, "your mollibloomers is shewin"' (36) in the novel, and the following passage testifies to a desire to signal the filiation between In Transit and Ulysses: "Should I snatch it [the microphone] and announce to all In Transit my tribute to my great Triestine compalien, the comedi-chameleon, the old pun gent himself? I could loose on the Lounge his obituary: I am the voyce of one crying in the wilderness; reJoyce with me" (36). However, according to Lawrence, "if the novel names Joyce as transcultural forefather, it nevertheless also treats him as a father who must be outgrown" (173). As analyzed by Lawrence, there is in this passage both "homage and disaffiliation", along with "an acknowledgment that however important Joyce is as a precursor, the way forward is not the same as the way back" (Lawrence 2010, 179). The invitation to "reJoyce" with the narrator leads the reader to recognize the intertextual dimension of a text that borrows its style from a modernist precursor, epitomizing Hutcheon's notion that parody is "a form of repetition with ironic critical distance, marking difference rather than similarity" (xii). Within the tribute paid to the master, the difference inserted within continuity is the metafictional attitude of the narrator, constantly inviting readers to distance themselves from the text by pointing to its artificiality, to the conventions it follows and to the underlying writing processes.

Within that overarching frame of reference parodying the style and digressive structure of both Joyce's and Sterne's works, the text is interspersed with various other "sub-parodies" of different genres-a non-exhaustive list of which comprises Pauline Réage's pornographic novel Histoire d'O turned into Histoire de la langue d'Oc (101-104), a detective novel, a medieval romance (159-160) or back-cover literary reviews (99-101). The novel also tackles various art forms and media, including a parody of a baroque opera, entitled Alitalia (49-59), that of the game show What's My Line? turned into What's My Kink? (133-138), a pastiche of a tabloid (45-46) or a parody of Raymond Burr's character Perry Mason in the eponymous TV series (161-164). This non-exhaustive list shows that the novel establishes multiple frames of reference, turning the novel into a playful and heterogeneous intertextual patchwork for the reader to navigate. It also offers an opportunity to lay bare the writing process and conventions of various materials, as exemplified by the parody of Réage's Histoire d'O. Pat picks up a book from a bookstall, The Story of Oc's Tongue, and while s/he starts reading, s/he seems to be annotating the text with "a pseudo-scholarly commentary" (102). The layout of the page is subsequently split into two columns: the first one displaying a pastiche of a pornographic novel, showing Oc blindfolded and tied up, ready to be taught a language 
lesson by a mysterious " 'He" " holding a riding-crop. The second column shows the narrator's marginal comments: "Note the cardinal rôle [sic] taken in pornography by ritual: cf. the anxiety-allaying rôle [sic] of ritual in obsessional neurotic acts (e.g. religious ones)" (103) or "One must of course emend wordy to worthy, meanwhile querying whether the high incidence of misprints in pornography and thrillers results from (i) printing in a foreign country or (ii) the fact that when the story is exploded it's exploded, with the result that no one can bear to read it through twice" (104). This passage aptly demonstrates Brophy's parodic technique and its ambivalence. On the one hand, the hypotext is reproduced with little to no alteration, including all its stylistic idiosyncrasies such as " $\mathrm{He}$ " " incorrectly capitalized and placed in inverted commas for emphasis, in the manner of a pastiche copying the original text. It is thus inscribed as such within the very fabric of the novel, demonstrating a degree of "sympathy" for the parodied text (Rose 51). On the other hand, the marginal metacomments bitterly draw the attention of the reader to the poor quality of the text while laying bare the underlying conventions that structure the pornographic genre, with the effect of honoring the original text while taking a critical stance at the same time.

In the words of Daniel Sangsue, parody is fundamentally "contradictory": it may seem "conservative" as it reproduces the literary discourses of authority, yet it is also revolutionary as it subverts these discourses, introducing "difference within continuity" (Sangsue 84-85). Brophy's parody resolutely takes this both/and approach, paying homage to the hypotexts that are featured in the novel while inviting readers to distance themselves from the conventions they are built on. In the second part, I would like to argue that Brophy not only draws attention to the processes of novel writing but she also subverts and breaks those referential frames, so as to perfectly reflect the character's conundrum regarding their sex.

\section{Breaking the frames of genre and gender}

In In Transit, the multiple intertextual references to various literary genres offer an equal number of opportunities to explore and expose the conventions at the heart of highly codified and discursively constructed gendered roles. Later in the book, Pat, still investigating what his or her biological sex may be, turns into Slim O'Rooley (154), a private eye looking for a now stolen member. While on a case, O'Rooley "because of his dislike of his own name, of his very self" often uses aliases such as "The Knight Errand", "The Chevalier O'Hooligan" (159) or "Sir Patrice" (160). During the investigation, Patricia-O'Rooley's secretary, also known as "Bunny"-is abducted. The detective story then morphs into an epic narrative, where O'Rooley turns into Oruleus, a brave knight who has to face the conveyor belt, depicted as a formidable two-way monster, Amphisbaena (179), in order to save the damsel in distress.

The shift from one genre to the other reveals the perpetuation of similar, typical roles consistently assigned to men and women across time and stories. Indeed, while generic code-switching is indicated by a different range of vocabulary and different names for the characters, the architecture of the plot and the parts played by the characters within that structure remain unchanged. In an essay entitled "Detective Fiction: A Modern Myth of Violence?", Brigid Brophy examines the filiation between the Greek hero of oral tradition and the modern detective: 
The countless stories we generically call 'the detective story' resemble a group of myths, inasmuch as there is really only one skeleton detective story, on which detective writers invent variations consciously (which probably separates them from the anonymous and no doubt multiple authors of myths) and more or less ingeniously. [...] It is these fictions which are our latterday myths. Although they carry an author's name (or very often, pseudonym), they shew [sic] the mythological tendency to repeat a standard pattern with variations conspicuous but superficial, and their heroes come close to the mythological type of the hero. $(1965,12 ; 18)$

In the passage mentioned above, the seamless morphing of the detective story into the epic genre makes that "skeleton" obvious. As parody underlines the resilience of generic patterns underlying such mythical stories, it bares the discursively constructed conventions opposing parts of male heroes to vulnerable female victims.

As stressed by Margaret Rose, "[i]n much meta-fictional parody, familiar literary structures may also be deliberately 'foregrounded' or brought into the 'foreground' of a work from its background structure, by being made more obvious, more complex, or confusing through the contrast of works in the parody" (Rose 52). To this effect, the conventions of the literary genres are overstressed in the novel in order to reveal the part they play in the elaboration of gendered norms. While O'Rooley's discourse is essentially marked by a concern with facts and "Logic" (162-163), Bunny is described as being encouraging, solicitous and admiring (164) towards her superior, a point that is driven home when the character recommends that O'Rooley take care of himself four times in the span of two pages: "You will take care of yourself, chief?", "“You will be careful, chief?"' (164); “"Take care of yourself”, “'You work too hard chief” (165). The female character seems to be constrained within a limited set of remarks, all focused on the male hero's well-being. This exaggerated psittacism, or mechanical repeating of words, brings to the fore the stereotypical gender roles featured in detective stories.

Interestingly, most of the parodies only make sense when read in the light of each other, placing cross-pollination between genres at the core of Brophy's practice of intertextuality; a practice foreboding what Judith Butler would later on describe as "a set of parodic practices based on a performative theory of gender acts that disrupt the categories of the body, sex, gender, and sexuality and occasion their subversive resignification and proliferation beyond the binary frame" (1990, xxxi). During the epic passage, the hero Oruleus recognizes "the paleness of a fair skin exposed" (160) within the circle formed by the metallic serpent. "Naked, bound and gagged, the maiden Patricia stood chained, her arms stretched above her head, to an iron ring affixed to the central pillar" (160). Even though Patricia is depicted as a fair maiden, which is consistent with the conventions of epic romances, the references to her being gagged and chained unquestionably echo The Story of Oc's Tongue. The implication is twofold: on the one hand, the hybridization of romance and pornography emphasizes that the roles assigned to female characters in epic narratives, pornographic novels or thrillersamong others-are unswervingly those of rather passive and submissive foils, conveniently providing opportunities for the male hero to demonstrate his heroism or power. Concurrently, the porosity between overlapping literary genres, coupled with the fact that Pat simultaneously embodies both the male hero and his female counterpart, undermine the rigidity of such gendered conventions. Parodic proliferation allows the text to morph endlessly into various generic shapes, mirroring the character's ability to assume multiple sexual and gendered identities. Both textual 
and sexual conventions are reframed outside binary and mutually exclusive categories that are redefined in terms of simultaneity, fluidity and diversity.

Another telling instance of a character breaking its narrative frame is seen when Oc reappears at the end of the story as Och, a Scottish-Irish student (195), "both genuinely young and studious in learning" (195). A feminist revolution has taken place in the transit lounge, where lectures and conferences are being held in support of the feminist movement. Och ventures a question to the male speaker giving a talk on John Donne: “'I'm afraid I wasn't here at the beginning, and I know it's a naïve question, but I wonder if you would just tell me John Donne's dates. I mean: when was he born and when did he die?"'. The speaker answers this straightforward question with a rather opaque statement that his "deep conviction [is] that John Donne somehow speaks directly to our condition" and could be defined as an "instant human condition" himself (195). In response to the lecturer's obscure and irrelevant answer, Och automatically assumes that her query was badly phrased and apologizes (196). The meaning of this scene is to be understood in the light of the previous appearances of Oc in the narrative, being taught a language lesson by a master. The compliant and apologetic attitude of the female student is superimposed, in the mind of the reader, upon the patterns of submissiveness observed in the earlier responses of the character, establishing a direct link between the conventional roles attributed to females in literature and the social conventions. According to Butler, "parodic proliferation deprives hegemonic culture and its critics of the claim to naturalized or essentialist gender identities. Although the gender meanings taken up in these parodic styles are clearly part of hegemonic, misogynist culture, they are nevertheless denaturalized and mobilized through their parodic recontextualization" (Butler 176). In this instance, the parodic repetitions displayed in Brophy's novel retain the strength of the ambivalence noted by Butler: while repeating the patterns of male-centered discourses of authority, the permeability of the referential frames allows for a critical rethinking of gender roles as they are depicted in art and literature and denaturalizes the social norms that reflect them.

In Transit abounds in such examples of parodic recontextualization and resignification. For instance, O'Rooley is placed in a comedic situation that similarly blows the mechanisms of suspense in detective fiction out of proportions through repetition. Pat warily opens three doors during the course of the scene, barreling into the room to counteract the enemies that are expected to wait in ambush behind the door. Each time, his expectations (and the reader's) are thwarted. The comedic device, repeated a fourth time, results in the character being careless and knocked down on the floor during the fourth door-opening. Likewise, in a final turn of the screw, the reader's suspicion that Bunny the secretary has morphed into Oc is confirmed, when Oruleus sets her free from her restraints and she exclaims: "What the hell do you think you are doing? I'm a bondage fanatic.' [...] 'Kindly adjust my bonds before leaving”' (179). In this burlesque twist, Brophy reverses the relations of power, while deflating the heroic move of the knight as though pushing objects around on a chessboard. By the end of the scene, Oruleus, unmanned, turns into Patricia again. Sonya Andermarh analyzes a similar earlier scene, during which Oc is given a language lesson (144). The witty exchange between Oc and the Master plays on both meanings of the word "tongue", understood as a body part and a national language at the same time. According to Andermarh, "By having Oc give 'cheek,' Brophy parodies the idea that the male is the dominant figure in the scene, so that power resides in the supposedly masochistic 'OC' 
rather than with 'The Master.' The function of such absurd and comic punning is to deflate his phallic presumption of power" (Andermarh 8).

As established, every occurrence of the character of $\mathrm{Oc} / \mathrm{h}$ reframes the issue of the male/female power relationships. In Rose's terms, the conventions are both foregrounded, and made "more complex or confusing" (52) at the same time, providing space to rework pre-scripted material in order to undo normative prescriptions. Brophy's post-modern metafictional parody intentionally brings familiar literary conventions and structures to the forefront in order to better introduce a political feminist agenda. The intertextual and intermedial references at play in the novel allow for a simultaneous exploration and subversion of both textual and sexual norms through a practice of parody based on repetition, exaggeration, hybridization and metalanguage, with a view to rewriting gender roles through each new iteration.

\section{A Baroque aesthetics of parody}

In Baroque-' $n$ '-Roll and Other Essays, Brigid Brophy observes features comparable to her practice of parody in the baroque genre: "Baroque is an open, sometimes an explosive embrace of contradictions, intellectual and of feeling. Ambiguity and puns are its raw material merely. Its essence is the ambivalence, in full deep psychoanalytic import, of emotions. It is a pair of giant curly brackets that clip together things irreconcilable" (1987, 149). Ambivalence and ambiguity, previously identified as dominant characteristics of postmodern parody by Hutcheon and Rose are also defined as the main components of the baroque aesthetics by Brophy. It is no accident then that curly brackets are used recurrently in the novel, in order to clip together two words (47), or sometimes two letters within a word (51) to introduce an array of options and meanings within a single item and to metonymically materialize within words themselves the "explosive embrace" of contradictions that is the novel. Bernard Hoepffner, Brophy's translator, further demonstrates the ambiguity of certain puns that contain multiple layers of meaning. In the following example-"Cynoscephalae, ladies, sigh no tom-moore" (35)-he notices no fewer than four allusions that are part and parcel of the humorous dimension of the phrase "(a) 'dog-headed Irish slips' two lines higher, (b) the battle of Cynoscephalae, (c) 'Sigh no more, ladies, sigh no more' from Much Ado About Nothing, and (d) Thomas Moore, the author of patriotic Irish songs" (Hoepffner 1995). The word "Cynoscephalae" is to be understood first as an adjective, then as a proper name. The phonetic dimension of the term also needs to be considered, in order to understand the homophonic pun with "sigh no". Unpacking this single segment requires knowledge of ancient history, of Renaissance literature and of nineteenth-century poetry, making the translating-and reading-process that much harder, with puns seemingly "impossible to transpose into another language" (Hoepffner 1995). Such hermeneutic complexity is precisely a baroque feature, according to Benito Pelegrin's examination of the genre:

Un déluge d'informations noie le message et l'on flotte quelque peu à pénétrer un dessein autant qu'à cerner un dessin que la couleur estompe et la distance embrouille. La saturation du sens, des sens, finit par fondre la signification, confondre l'esprit. La multiplication des perspectives, des points de vue, des pistes possibles rend labyrinthique l'approche et problématique le Sens unique, total et totalitaire [...] : à trop illustrer le message, il n'est plus qu'illustration. (353) 
17 In In Transit, the excessive degree to which the conventions of genres, genders and languages are exploited, exaggerated, deconstructed and subverted leads to a slow disintegration of one coherent meaning in order to produce plural, ambiguous implications. In his/her metacritical fashion, Pat comments, during an interlude addressed to the reader: "ALIENATING INTERLUDE. The management trusts the clientele has by now observed that at least one of the hero(in)es immolated throughout these pages is language" (219). Such a sacrifice of the conventions of language and basic grammar progressively disintegrating into playful, musical punning complexifies the interpretative process. The endlessly digressive text, always differing the end of the quest for the sex of the character, operates on a principle of frustration that ultimately tests the resistance and resilience of the reader to this undoing of the normative conquest. According to Jean-Michel Ganteau:

\begin{abstract}
The baroque persuasion at work through In Transit appears as a way to promote the creation of an all-embracing narrative apparatus that maintains contradictions, subverts the basic rules of logic, makes contraries coexist, frustrating the reader of any of the staple components of narrative pleasure, i.e.: linearity, closure and identification. Instead of mere opposition or contradiction, we are thus presented with a text that favours suspended dialectics and permanent openness [...]. (Ganteau 198)
\end{abstract}

Indeed, the baroque process of clipping contradictory elements together shows its own limits, for the curly bracket that holds disparate pieces together also aptly figures the opposite forces at work in the text, as it strives to unite parts that the centrifugal force of deconstruction pulls apart. During the final chapter, Och the student confides in an elderly female linguistics professor, and the following dialogue sums up Brophy's entropic creative process:

'To be absolutely frank, what I should most like to resemble is a small but powerful and concentrated bomb. My ambition is to explode and shatter the rules.'

'Splendider and splendider! You have the true violent spirit of the creative artist. It is by the setting off of bombs inside the existing framework of the arts that new artistic forms come into being'.

'And yet for all my creative energy I feel impotent,' Och sadly said. 'I can't find anyone who will teach me the rules. So how can I make sure of breaking them?' (197)

Brophy's metafictional parody lays bare the rules, both social, literary and linguistic, for the reader to understand before the "creative artist" may break or "explode" those norms, in a baroque fashion. This motif appears once again very literally, through a character named Baroco, an airport employee who decides to plant an explosive in a model of the airport, hoping to "create a modern baroque" (201):

All the same, Baroco thought that the model bore enough resemblance to a work in a classical idiom to serve his purpose-which was to plant an explosive inside it, set it off and, out of the centrifugal disruption of the classical architectural members, create a modern baroque. [...] From its explosion, he anticipated there must be reborn something of the true, the grotesque and the beautiful baroque incongruity. [...] It might, indeed, be a positively surrealist baroque he was about to create. (201)

Brigid Brophy and her practice of parody may be compared to this character hoping to create a modern or "surrealist" baroque: experimenting with classical material, playing with various styles and art forms jarringly superimposed, and testing the limits of reproducing a norm that degenerates in the text, in order to fashion a literary and linguistic baroque monster. Such a writing process, which quite literally places 
planting bombs within classical structures at the core of artistic creation and deprives its readers of the comfort of traditional storytelling, may lead to aporia. However, it also encourages readers to adopt new reading strategies, embracing instability, openness and inventiveness.

21 According to Carole Sweeney, Brophy possessed "an acute understanding that language was one of women's most intransigent enemies in the struggle for even the most rudimentary gender equality" (314). Such a consideration is also central to Judith's Butler queer theory in Gender Trouble: "If gender itself is naturalized through grammatical norms [...] then the alteration of gender at the most fundamental epistemic level will be conducted, in part, though contesting the grammar in which gender is given" (1990, xix). Pat expresses similar concerns and hypothesizes: "Suppose the structure which, like an organic conveyor belt, has been transporting all my thoughts and experiences all these years is but an arbitrary convention?" (222). In order to demonstrate the relativity of such linguistic conventions, the narrator compares the grammatical expressions of gender in various romance languages (41-42), and stresses their generally "sex-obsessive" (42) quality: "They are sly, though, these romance languages, in the matter of sex. [...] They're sexsessive, too, the languages: but unsophisticatedly. I shed them in sheer impatience at the infantility of their sexual curiosity. I do not want to be told the sex of inanimate objects" (41-42). Brophy's feminist agenda of parodic deconstruction includes the very structures of language, which she proceeds to subvert in order to invent a medium able to convey the gendered ambiguity of her character. The portmanteau word "sexsessive" for instance, created by grafting the word "sex" to the adjective "excessive" illustrates the baroque writing strategy that consists in clipping together elements that should be syntactically irreconcilable. Similarly, in the following programmatic announcement: "We are people boned of our norms. Our programme:-Undo the Normative Conquest. Some items we have observed:-standard English sets no standard: the faut in comme il faut is no logical compulsion but our foe, the faux" (27), the playful echo between the homophones "faut", "faux" and "foe" breaks the boundaries between dialects in order to "undo the normative conquest" within the structures of languages. The accumulation of neologisms and portmanteau words, the creative typography, the Babelian quality of the text mixing French, Italian or Latin with English, the dual layout of the pages and the-occasionally bilingual-puns created by Brophy challenge the conventions of syntax, grammar and punctuation. Doing so, Brophy successfully crafts a hybrid linguistic material that can aptly express the contradictions of emotions and the instability of identity at the heart of her neo-baroque enterprise.

\section{Conclusion}

In Brophy's description of baroque paintings, "[t] he elements of the composition are convulsed as though by an explosion, the designer no longer seeks to balance one against another in a simulacrum of heavenly or geometric harmony; instead, he arrests and transfixes the explosion at the very point of disintegration" (Brophy 1987, 156). The entropic motifs of explosion and disintegration that Brophy defines as key visual elements of the baroque aesthetics emblematize the parodic process at the core of the novel. In In Transit, the classical material of literature is overstated and complicated through various strategies of exaggeration, refiguration and metafiction in order to 
better display the conventions on which it relies. This form of metafictional parody pays tribute to the hypotexts that it features, while its didacticism invites the readers to critically examine the bond that unites literature and social conventions. The diversity of intertextual and intermedial references explored in the novel concurrently subvert and reframe gender identities outside mutually exclusive binary categories. Along with a metalinguistic and didactic exposition of the rules of textual and sexual identification through overlapping parodies and resignification, the ultimate target of this methodical deconstruction are the norms regulating language itself. In order to expose the arbitrariness of the verbal structures that shape our understanding of reality and to undermine their power to model our perceptions, the parodic text is saturated with multiple meanings and innuendos, that may jeopardize the intelligibility and readability of the text. Concurrently, the humorous use of a hybrid and deregulated language produces meaning outside of the conventional rules of logic and syntax, to favour playfulness, ambivalence and musicality. In baroque fashion, In Transit succeeds in setting bombs at the heart of narrative conventions, literary canons, gendered norms and grammatical rules while it transfixes the explosion "at the very point of disintegration".

\section{BIBLIOGRAPHY}

Andermahr, Sonya. "Both/And Aesthetics: Gender, Art, and Language in Brigid Brophy's In Transit and Ali Smith's How To Be Both". Contemporary Women's Writing 12.2 (September 15, 2018): 248-263.

Brophy, Brigid. “Detective Fiction: A Modern Myth of Violence?” The Hudson Review 18.1 (1965): 11-30.

Brophy, Brigid. In Transit: An Heroi-cyclic Novel (1969). London: Penguin, 1971.

Brophy, Brigid. Baroque-' $n$ '-Roll and Other Essays. London: Hamish Hamilton, 1987.

Butler, Judith. Gender Trouble: Feminism and the Subversion of Identity (1990). New York: Routledge, 1999.

Ganteau, Jean-Michel. "In Thy Autonomy is Thy Commitment: Brigid Brophy's In Transit". Autonomy and Commitment in Twentieth-Century British Literature. Christine Reynier and Jean-Michel Ganteau (eds.). Montpellier: PU de la Méditerranée, 2010, 191-201.

Hutcheon, Linda. A Theory of Parody: The Teachings of Twentieth-Century Art Forms (1985). Urbana: U of Illinois $\mathrm{P}, 2000$.

Hoepffner, Bernard. “Translating In Transit: Writing-by Proxy”. The Review of Contemporary Fiction 15.3 (1995): 54-61.

Lawrence, Karen. “Joyce in Transit”. Who's Afraid of James Joyce? The Florida James Joyce Series. Gainesville: UP of Florida, 2010, 168-179.

Pelegrin, Benito. Figurations de l'infini : l'âge baroque européen. Paris: Éditions du Seuil, 2000. 
Rose, Margaret A. Parody: Ancient, Modern, and Post-Modern. Cambridge: Cambridge UP, 1993.

Sangsue, Daniel. La Relation Parodique. Paris: José Corti, 2007.

Sterne, Lawrence. Tristam Shandy. Howard Anderson (ed.). New York and London: Norton, 1980.

Sweeney, Carole. “'Groping inside Language': Translation, Humour and Experiment in Christine Brooke-Rose's Between and Brigid Brophy's In Transit”. Textual Practice 32.2 (February 7, 2018):

301-316. https://doi.org/10.1080/0950236X.2018.1413047 (last accessed 18 April 2020).

Vichnar, David. “The Fearless Iconoclast: On Brigid Brophy's In Transit”. Equus Press, 18 Aug.

2014. https://equuspress.wordpress.com/2014/08/18/the-fearless-iconoclast/ (last accessed 18 April 2020).

\section{ABSTRACTS}

Brigid Brophy's In Transit, published in 1969, is a complex experimental novel that focuses on the motif of disintegration. The plot centers on the main character and focalizer, Pat(ricia), who realizes s/he has forgotten his/her biological sex. A picaresque quest for this missing piece of information through the transit lounge ensues, following the character's multiple attempts to deduce his/her sex from clues, attitudes, and dialogues with other characters. Throughout the novel, each new effort to decipher signs and behaviors takes the form of a different literary genre or artistic form, be it an opera, a detective story, a pornographic novel, or a televised game show. With the fundamentally ambivalent dimension of parody as defined by both Margaret Rose and Linda Hutcheon in mind, I would like to focus first on the novel conceived as a laboratory to experiment on the literary conventions of various genres, in an attitude ranging from sympathy to criticism towards its hypotexts. This will lead me to explore the relationship between the notions of genre and gender, and to demonstrate the simultaneous subversion of both literary and gendered norms. Finally, I would like to concentrate on the entropic motif at work in the text, showing how the destruction of gendered, literary but also linguistic norms ultimately leads to a baroque parody.

Cet article se propose d'explorer les aspects de la parodie dans le roman expérimental de Brigid Brophy, In Transit, publié en 1969. Le roman met en scène Pat(ricia), le personnage principal frappé simultanément d'une amnésie identitaire et de lèpre linguistique, dans la recherche effrénée de son sexe biologique oublié à travers la zone d'embarquement d'un aéroport. Chaque nouvelle tentative du personnage prend la forme d'un genre artistique ou littéraire différent, mêlant parodies de roman noir, opéra, jeux télévisés et roman pornographique. Avec pour ligne directrice la nature fondamentalement ambivalente de la parodie telle qu'elle est définie par Margaret Rose et Linda Hutcheon, cet article s'attachera à explorer dans un premier temps les différents hypotextes parodiés, et la posture tantôt empathique, tantôt critique du texte cible par rapport au texte source. Cet article examinera dans un deuxième temps les multiples infractions faites aux codes de genre, intimement liées à celles faites aux identités de genre. Enfin, nous examinerons comment cette dynamique de l'infraction mène en dernier ressort à la création d'une parodie baroque fondée sur la désintégration des normes, qu'elles soient sociales, littéraires ou linguistiques. 
INDEX

Mots-clés: parodie, genre, baroque, norme

Keywords: parody, gender, genre, norm, baroque

oeuvrecitee In Transit

\section{AUTHORS}

\section{JUSTINE GONNEAUD}

Justine Gonneaud is a doctor of English literature and a senior lecturer at the University of Avignon. Her research focuses on issues of ethics, gender and the representation of LGBTQIA+ identities in contemporary British literature, and more recently, on the poetics and politics of urbanity. She has published articles on the works of authors such as Will Self, Jeanette Winterson, Angela Carter, Peter Ackroyd, and Jackie Kay. 